\title{
PENGARUH PENGETAHUAN KESEHATAN REPRODUKSI TERHADAP PERILAKU SEKSUAL PRA NIKAH PADA MAHASISWA AKPER DI YOGYAKARTA
}

\author{
Wiwi Kustio Priliana ${ }^{1}$ \\ ${ }^{1}$ Akper Notokusumo Yogyakarta, Jalan Bener no.26 Tegalrejo Yogyakarta, Daerah Istimewa Yogyakarta \\ 55112, email: wiwi_kustio@yahoo.com
}

\begin{abstract}
Background: In Indonesia about 15\% of adolescents aged 10-24 years have been having sex outside of marriage. Indonesian teenagers today are more tolerant of premarital sexual lifestyle. This is evident from the research results of various institutions in Indonesia during the period 1993-2002, found that 5-10\% of women and $18-38 \%$ of young men aged 16-24 years have had premarital sexual relations with their age partner. Other research results also said that the cause of premarital sexual behavior in adolescents because of knowledge about reproductive health. Knowledge of reproductive health is considered taboo to be discussed. This is precisely pushing the knowledge of adolescent to sexual becomes more. Objective: Knowing the description of Akper students who have engaged in sexual behavior influenced by knowledge of reproductive health .

Methods:This type of research is an observational study using cross sectional study design. Results: Students who have high reproductive health knowledge are more than $65,9 \%$ in mild prenatal sexual behavior. Students with low level of knowledge have a chance of having a mild pre-marital behavior 2 times higher than students with high knowledge of reproductive health. From the results of bivariable analysis, both variable a significant relationship with premarital sexual behavior with a value of $p<0,05$.

Conclusion; Akper students who have premarital sexual behavior are $69.9 \%$. They tend to engage in premarital sexual behavior then have a low reproductive health risk. Category of premarital sexual behavior includes holding hands, hugging, kissing dry (kissing the cheeks or forehead) and kissing wet (kissing the lips). Premarital sexual behavior is caused by high knowledge of reproductive health.
\end{abstract}

Keyword: Premarital sexual behavior and knowledge of reproductive health

\section{PENDAHULUAN}

National

Adolescent

Health

Information Center (NAHIC) memperkirakan jumlah remaja di tahun 2003 meningkat dari $18,5 \%$ tahun 1980 menjadi $45 \%$ tahun 2025 (National Adolescent Health Information Center, 2003). Berdasarkan data dari badan Pusat Statistik di Indonesia jumlah remaja lebih dari 42,4 juta. ${ }^{1}$ Pada usia remaja biasanya hubungan seksual terjadi, karena pada usia tersebut sedang tumbuh dewasa dimana saat itu mulai timbul dorongandorongan seksual dalam diri mereka. Pada masa tersebut minat mereka dalam membina terfokus pada lawan jenis. $^{2}$

Banyak remaja yang belum begitu mengerti bahaya penyimpangan dalam perilaku seks pranikah. Remaja tidak berpikir secara logika tentang apa yang mereka lakukan. Banyak faktor yang menjadi penyebab terjadinya seks pranikah pada remaja. Salah satunya ialah rendahnya pengetahuan yang dimiliki remaja mengenai seksualitas. Pengetahuan yang disampaikan sering berisi informasi tidak lengkap dan tidak benar karena diperoleh dari sumber yang keliru dan masih adanya anggapan 
seksualitas adalah hal tabu untuk dibicarakan.

Hasil penelitian yang yang telah dilakukan mengatakan bahwa penyebab timbulnya perilaku seks pranikah pada remaja karena rendahnya pengetahuan tentang kesehatan reproduksi. ${ }^{3}$ Pengetahuan seksual pranikah penting karena dapat mempengaruhi sikap individu terhadap seksual pranikah. ${ }^{4}$ Selama ini pengetahuan kesehatan reproduksi dianggap tabu untuk dibicarakan. Hal ini justru mendorong pengetahuan remaja terhadap seksual menjadi besar. Para pengamat dan peneliti remaja hanya melakukan himbauan agar para orang tua memberikan arahan yang tepat dan ketat, sementara remaja dihimbau untuk memperkuat konsep dirinya. Remaja memiliki karakteristik selalu ingin tahu dan mencoba-coba. Hal tersebut membuat

\section{BAHAN DAN CARA PENELITIAN}

Penelitian ini dilaksanakan di Akademi Keperawatan Notokusumo Yogyakarta pada bulan November .2015. Populasi dalam penelitian ini adalah mahasiswa Akper Notokusumo Yogyakarta Dengan sampel mahasiswa TK I dan II.Akper Notokusumo Yogyakarta.

Jenis penelitian ini adalah penelitian observasional dengan menggunakan rancangan studi potong lintang (cross sectional study). Penelitian cross sectional adalah jenis penelitian yang mencari hubungan antara variabel bebas (paparan) remaja cenderung lebih permisif terhadap perilaku seksual pranikah. ${ }^{5}$ Perilaku seksual pranikah merupakan persoalan multidimensional, dipengaruhi berbagai faktor baik dari dalam maupun luar diri remaja. Faktor dari dalam diri atau faktor personal seperti karakteristik remaja, faktor dari luar adalah keluarga, sekolah, dan lingkungan sekitarnya dapat untuk memprediksi aktivitas seksual remaja. ${ }^{6}$ Secara garis besar, faktor yang bisa menerangkan perilaku seks pranikah dibagi menjadi 2, yaitu: faktor internal dan eksternal. Faktor eksternal (luar individu) adalah faktor lingkungan dimana remaja tersebut tinggal yang mencakup norma sosial, kehidupan bermasyarakat dan pengaruh orang lain seperti orang tua dan teman sebaya (peer group). Sedangkan faktor internal (individu) meliputi karakteristik individu, regulasi diri, efikasi diri, sikap dan pengetahuan. ${ }^{7}$ dengan variabel terikat (efek), di mana kedua variabel ini diamati secara serentak pada satu saat atau periode waktu tertentu.

\section{HASIL DAN PEMBAHASAN}

Hasil penelitian pengaruh pengetahuan tentang reproduksi terhadap perilaku seksual Pranikah adalah sebagai berikut:

Dari tabel 1 diatas terlihat bahwa mahasiswa akper notokusumo untuk variabel perilaku seks pranikah pada mahasiswa Akper Notokusumo menunjukan bahwa perilaku seks berat sebanyak 174 mahasiswa (58 \%) dan perilaku seks ringan sebanyak 
126 mahasiswa (42\%). pengetahuan kesehaan reproduksi tinggi sebanyak 217 mahasiswa $(72,3 \%)$ dan pengetahuan kesehatan reproduksi rendah sebanyak 83 mahasiswa $(27,7 \%)$.

Tabel 1.Gambaran Perilaku Seksual Pranikah, Pengetahun Kesehatan Reproduksi mahasiswa Akper Notokusumo.

\begin{tabular}{lrr}
\hline Variabel & N & $\%$ \\
\hline $\begin{array}{l}\text { Perilaku Seks } \\
\text { Pranikah }\end{array}$ & & \\
\hline \multicolumn{1}{c}{ Berat } & 174 & 58,0 \\
\hline \multicolumn{1}{|l}{ Ringan } & 126 & 42,0 \\
\hline $\begin{array}{l}\text { Pengetahuan } \\
\text { kesehatan } \\
\text { reproduksi }\end{array}$ & & \\
\hline \multicolumn{1}{c}{ Tinggi } & & \\
\hline \multicolumn{1}{l}{ Rendah } & 217 & 72,3 \\
\hline
\end{tabular}

Tabel 2.Hubungan Perilaku Seksual Pranikah mahasiswa dan Pengetahuan Kesehatan Reproduksi

\begin{tabular}{|c|c|c|c|c|c|c|c|c|}
\hline & & Peri & ku & Seks & Pranil & & & \\
\hline & Ring & & $\mathrm{Be}$ & & $\chi^{2}$ & $\mathbf{P}$ & $\mathbf{R P}$ & IK \\
\hline & $\mathbf{n}$ & $\%$ & $\mathbf{N}$ & $\%$ & & & & \\
\hline $\begin{array}{l}\text { Penget } \\
\text { ahuan } \\
\text { kespro }\end{array}$ & & & & & & & & \\
\hline Tinggi & 143 & 65,9 & 74 & 34,1 & 20,08 & 0,001 & 1,76 & $\begin{array}{c}1,31 \\
- \\
2,36\end{array}$ \\
\hline
\end{tabular}

$\begin{array}{lllll}\text { Rendah } & 31 & 37,3 & 52 & 62,7\end{array}$

Keterangan RP: Rasio Prevalensi, p: p-value IK 95\%; Interval Konfidensi, * : Signifikan

Pada tabel 2 variabel pengetahuan kesehatan reproduksi, menunjukkan bahwa mahasiswa yang memiliki pengetahuan kesehatan reproduksi yang tinggi lebih banyak $65,9 \%$ dalam berperilaku seksual pranikah ringan jika dibandingkan dengan mahasiswa yang berpengetahuan kesehatan reproduksi rendah. Dalam tabel menunjukan bahwa mahasiswa yang mempunya pengetahuan kespro nya rendah berpeluang melakukan perilaku pra nikah ringan 2 kali lebih tinggi dari mahasiswa yang mempunya pengetahuan kespro rendah.

Dari hasil analisis bivariabel,ternyata keduanya menunjukkan hubungan yang signifikan dengan perilaku seksual pranikah dengan nilai $p<0,05$

Pengetahuan adalah merupakan hasil dari tahu dan ini terjadi setelah orang melakukan pengindraan suatu objek tertentu. Pengetahuan atau kognitif merupakan domain yang merupakan sangat penting untuk terbentuknya tindakan seseorang. Pengetahuan dan perilaku memiliki hubungan yang sangat erat. Jika pengetahuan tentang kesehatan reproduksi baik, maka akan semakin baik pula perilaku seksualnya. Perilaku yang didasari oleh pengetahuan akan lebih langgeng dari pada perilaku yang tidak didasari oleh pengetahuan. ${ }^{8}$ Pengetahuan remaja tentang kesehatan reproduksi sangat penting dalam perilaku yang berhubungan dengan hubungan seksual (intercourse) pranikah. Pengetahuan tentang kesehatan reproduksi tersebut berisi informasi mengenai kesehatan reproduksi secara keseluruhan, seperti pengetahuan dasar tentang sistem organ reproduksi manusia, kontrasepsi keluarga berencana, 
serta penyakit menular seksual termasuk HIV/AIDS. ${ }^{9}$

Hasil analisis univariabel

menunjukkan bahwa sebanyak 217 mahasiswa $(72,3 \%)$ memiliki pengetahuan tinggi tentang kesehatan reproduksi. Analisis bivariabel, menunjukkan bahwa mahasiswa yang memiliki pengetahuan kesehatan reproduksi tinggi lebih banyak $65,9 \%$ dalam berperilaku seksual pranikah ringan jika dibandingkan dengan mahasiswa berpengetahuan kesehatan reproduksi rendah dengan nilai p 0,001 yang berarti bahwa variabel pengetahuan kesehatan reproduksi memiliki hubungan signifikan terhadap terjadinya perilaku seksual pranikah ringan pada mahasiswa. Hasil penelitian bahwa hubungan yang bermakna antara pengetahuan kesehatan reproduksi remaja dengan sikap remaja terhadap hubungan seksual (intercourse) pranikah mahasiswa. ${ }^{10}$

Dari hasil analisis univariabel diketahui bahwa mayoritas mahasiswa dalam sampel penelitian memiliki tingkat pengetahuan kesehatan reproduksi tinggi. Dalam analisis bivariabel, pengetahuan kesehatan reproduksi tinggi memiliki hubungan yang signifikan dalam terbentuknya perilaku seksual pranikah ringan pada mahasiswa. Pengetahuan tentang seksualitas memiliki dampak negatif terhadap perilaku seks dan tidak signifikan terhadap perilaku seks aman. ${ }^{11}$ Remaja yang memiliki pengetahuan seks yang tinggi memiliki perilaku seks positif lebih rendah dan cenderung tidak melakukan perilaku seks. Jadi meskipun remaja memiliki tingkat pengetahuan kesehatan reproduksi tinggi, namun tidak menjamin mahasiswa untuk tidak berperilaku seksual pranikah ringan. ${ }^{12}$ Variabel pengetahuan kesehatan reproduksi tinggi berhubungan secara signifikan dengan terjadinya perilaku seksual pranikah ringan. Rata-rata pendidikan kesehatan pada mahasiswa mempunyai pengetahuan kesehatan reproduksi tinggi. Pada dasarnya pengetahuan tentang kesehatan reproduksi memiliki efek negatif terhadap sikap seksual dan perilaku seksual yang tidak aman. ${ }^{13}$ Remaja dengan tingkat pengetahuan kesehatan reproduksi yang tinggi cenderung berperilaku seksual negatif dan tidak menunjukkan peningkatan dalam praktek perilaku seksual yang aman. ${ }^{14}$

\section{KESIMPULAN}

Mahasiswa Akper yang telah melakukan perilaku seksual pranikah ringan sebesar 69,9\%. Mereka cenderung berperilaku seksual pranikah ringan maka memiliki resiko kesehatan reproduksi yang rendah. Kategori perilaku seksual pranikah ringan meliputi berpegangan tangan, berpelukan, berciuman kering (mencium pipi atau kening) dan berciuman basah (mencium bibir). Perilaku seksual pranikah ringan disebabkan oleh pengetahuan kesehatan reproduksi tinggi. 


\section{KEPUSTAKAAN}

1. Adikusuma, I. Sikap remaja terhadap seks bebas di Kota Negara: Perspektif kajian budaya. Available: Ejournal. Unud. Ac ; 2005.

2. BPS \& Macro. International Survei Kesehatan Reproduksi Remaja 2007, Calverton Maryland, USA: Macro International; 2008.

3. Cahyo, K., Kurniawan., T. p. \& Margawati., A. TV dan Internet Beri Andi: Meledaknya Seks Pranikah. Jurnal Promosi Kesehatan Indonesia, 3 (2); 2008

4. Gordis, L. Epidemiology, Pennsylvania. W.B. Saunders Company; 2004.

5. Hatmadji, S. H. \& Rochani, S.Adolescent Reproductive Health in Indonesia. Research Report of Joint Cooperation. Jakarta: Demographic Institute Faculty of Economic University of Indonesia, The Ford Foundation, RAND Corporation: World Health Organization, and Yayasan Kusuma Buana; 1993.

6. National Adolescent Health Information Center Fact Sheet on Demographics: .2003

7. Tanjung, A :Kebutuhan Akan Informasi dan Pelayanan Kesehatan Reproduksi Remaja; Laporan Need Assessment di Kupang, Palembang, Singkawang, Cirecon dan Tasikmalaya, (Ed.rev): Jakarta: PKBI, BKKBN dan UNFPA: 2003.

8. Adolescents. NAHIC Briefs and Fact Sheets. San Francisco, CA: University of California, San Francisco. Newcomb, M. D., Huba, G. J. \& Bentler, P.
M.Determinants of sexual and dating behaviors among adolescents. $J$ Pers Soc Psychol, 50 (2): 428-38.; 1986.

9. Noor, S. Hubungan Pengetahuan Kesehatan Reproduksi Pada Remaja Dengan Kecenderungan Remaja Melakukan Hubungan Seksual (Intercourse) Pranikah di Indonesia (Analisis Data Survei Kesehatan Reproduksi Remaja Indonesia Tahun 2002-2003). Tesis, Program Pascasarjana IImu Kesehatan Masyarakat, Fakultas Kedokteran, Universitas Gadjah Mada; 2004

10. Lou, J. H. \& Chen, S. H. Relationships among sexual knowledge, sexual attitudes, and safe sex behaviour among adolescents: a structural equation model. Int J Nurs Stud, 46 (12): 1595-603.]; 2009.

11. Santrock, J. W. Adolescence Perkembangan Remaja, Jakarta: Erlangga; 2003.

12. Situmorang, R. A. P. Factors Influencing Premarital Sexual Intercourse Among Adolescents in Indonesia: A Case Study Among In-School Late Adolescents From Indonesian Young Adult Reproductive Health Survey (IYARHS) 2007. Thesis, Faculty of Graduate Studies, Mahidol University: 2011.

13. Track, F :The Psychology of Adolescence: Lightning Source Inc: 2009

14. Zimmer-Gembeck, M. J. The development of romantic relationships andadaptations in the system of peer relationships. Journal of Adolescent Health, 31: 2002. 